\title{
Géoarchéologie de sites préhistoriques
}

Jean-Laurent Monnier

\section{OpenEdition}

Journals

Édition électronique

URL : http://journals.openedition.org/rao/1423

DOI : $10.4000 /$ rao.1423

ISSN : $1775-3732$

\section{Éditeur}

Presses universitaires de Rennes

\section{Édition imprimée}

Date de publication : 31 décembre 2010

Pagination : 221

ISBN : 978-2-7535-1383-9

ISSN : 0767-709X

\section{Référence électronique}

Jean-Laurent Monnier, « Géoarchéologie de sites préhistoriques », Revue archéologique de l'Ouest [En ligne], 27 | 2010, mis en ligne le 25 février 2012, consulté le 04 décembre 2020. URL : http:// journals.openedition.org/rao/1423; DOI : https://doi.org/10.4000/rao.1423

Ce document a été généré automatiquement le 4 décembre 2020

Tous droits réservés 


\title{
Géoarchéologie de sites préhistoriques
}

\author{
Jean-Laurent Monnier
}

\section{RÉFÉRENCE}

Sordoillet, D., 2009 - Géoarchéologie de sites préhistoriques. Le Gardon (Ain), Montou

(Pyrénées-Orientales) et Saint-Alban (Isère). Paris, éditions de la Maison des Sciences de l'Homme (Documents d'Archéologie française, 103), 175 p. (ISBN 978-2-7351-1121-3 ; $40 €)$

1 Cet ouvrage est issu de la thèse de Dominique Sordoillet; c'est un volume de 175 pages comprenant un cahier de planches photos en couleurs.

2 La géoarchéologie est une discipline fondamentale en archéologie, quelles que soient les périodes étudiées. Elle contribue à la connaissance de la genèse des gisements, à celle des paléo-environnements, de la taphonomie et des actions anthropiques.

3 Ici, l'étude concerne trois sites très différents par leur position géographique, mais aussi par les périodes concernées. Le site de l'Ain (Le Gardon) comprend des couches qui s'étendent du Néolithique ancien au deuxième Âge du Fer; Montou, dans les Pyrénées-Orientales, se rapporte à une période qui va du Néolithique moyen au Bronze Final, tandis que le site de l'Isère est caractérisé par des occupations du Bronze final et du premier Âge du Fer.

4 Les données sédimentologiques, replacées dans leur cadre chrono-culturel, permettent de proposer des scénarios d'occupations et des interprétations sur l'évolution des pratiques, des rites ou des méthodes de construction.

5 Regrettons encore une fois, cependant, que la géoarchéologie se résume ici à la micromorphologie, certes utile mais très restrictive. L'étude est restreinte à la lithostratigraphie et à l'observation-interprétation des lames minces. Dans de tels 
contextes, il serait important de mettre en avant des études sédimentologiques complètes et de croiser les résultats des différentes méthodes.

6 Cependant l'ouvrage est clair et bien rédigé, parfaitement accessible pour le non spécialiste. Il comprend un lexique et une bibliographie importante; on ne peut qu'en recommander la lecture par la communauté des archéologues. 